\title{
O uso da autorregulação em alunos de bacharelado em trompete: um estudo exploratório no curso de música da Unicamp.
}

\section{lanca de Almeida Campos*}

\begin{abstract}
Resumo
A presente pesquisa faz uma reflexão sobre o uso da autorregulação em alunos de bacharelado em trompete do curso de música da Unicamp. O referencial teórico apoia-se no estudo de Zimmerman (1989) que estabelece três fases cíclicas de autorregulação, a saber: antecedente; controle de desempenho; e autorreflexão. Como resultado, o estudo proporciona uma compreensão do processo de autorregulação, permitindo uma prática instrumental de melhor eficiência no que tange a trajetória de estudos na área.
\end{abstract}

\section{Palavras-chave}

Trompete, autorregulação e autoensino.

\section{Introdução}

$\mathrm{O}$ ato de tocar um instrumento musical demanda diversas funções. Dentre essas funções destacam-se a corporal, a cognitiva e a emocional. Tais funções envolvem juntamente a combinação e ao mesmo tempo a interdependência de aspectos cognitivos e motores por meio de uma coordenação entre os sistemas auditivos e visuais, que permitem o controle das habilidades técnicas musicais (GALVÃO, 2006).

Este é um dos grandes desafios que permeiam o estudo dos trompetistas no curso de bacharelado em trompete da Unicamp. A fim de se obter determinadas habilidades musicais, os estudantes desse instrumento costumam dedicar-se em um estudo aplicado, em que muitas vezes, a prática massiva e deliberada, que comumente exige muitas horas de estudo, nem sempre surte o efeito esperado, pois, por si só, não garante um bom desempenho.

Um estudo consciente, realizado de forma organizada e planejada, contribui diretamente para um bom desempenho musical. Tais estratégias permitem que o próprio aluno de trompete, por meio de um grande número de execuções - tentativas assertivas e negativas - perceba as falhas em suas estratégias e consequentemente, em sua execução, culminando em uma autoavaliação eficiente. De acordo com Cavalcanti (2009) a "autorregulação é a capacidade de autoensino". Zimmerman (1989) elenca a categoria autorregulatória, na obra "A social cognitive view of self-regulated academic learning", que explicita as fases cíclicas que compõe a autorregulação no âmbito acadêmico.

\section{Resultados e Discussão}

Para obter informações necessárias para a pesquisa, primeiramente, foi aplicado um questionário a sete alunos trompetistas do curso de bacharelado em trompete da Unicamp. Esse questionário possuía 16 perguntas sobre como esses alunos estudam seus instrumentos de forma individual, com o propósito de coletar informações sobre as possibilidades de autoensino e de autoavaliação em sua prática musical.

A segunda parte da pesquisa deu-se por meio da gravação em vídeo de uma peça musical nunca estudada pelos participantes. A escolha da peça teve como finalidade proporcionar um desafio aos estudantes, porém, dentro de seus limites técnicos e interpretativos.
Á partir da análise da gravação dos vídeos e do questionário estabeleceu-se parâmetros de avaliação de acordo com as três fases cíclicas (antecedente; controle de desempenho; e autorreflexão), correlacionando-as com as perguntas a que estes estudantes foram submetidos. Essa análise permitiu demonstrar aos estudantes possíveis caminhos de preparação utilizando a autorregulação e o autoensino como estratégia

De acordo com a pesquisa, há alunos que realizaram o estudo proposto em um menor tempo e com resultados satisfatórios, em contrapartida, outros alunos obtiveram resultados também satisfatórios, em maior tempo. As estratégias de estudos foram muito parecidas, porém alguns alunos usaram diferentes práticas de estudo. O diferencial entre um aluno pesquisado e outro foi a maneira com que utilizou a concentração e o pensamento para resolver questões técnicas e interpretativas.

\section{Conclusões}

É possível aferir que todos os envolvidos na pesquisa que praticaram a audiação durante a gravação, tiveram um melhor resultado.

Cinco dos sete alunos entrevistados tiveram dificuldade em seguir o planejamento de seus estudos. Desses cinco alunos, três possuíam um alto grau de exigência, porém, se esqueceram de realizar um planejamento prévio dos estudos propostos.

Todos os alunos estudaram primeiramente os trechos musicais mais difíceis até que fosse possível interpretar os trechos inteiros.

A estratégia mais usada pelos alunos foi o estudo dos trechos mais difíceis, porém, os alunos que obtiveram os melhores resultados foram aqueles que praticaram a audiação e planejaram a forma como iriam executar o trecho inteiro solicitado.

\section{$\mathrm{PIBIC} / \mathrm{CNPq}$ e SAE}

\section{Agradecimentos}

CAVALCANTI, C. R. P. Auto-regulação e prática instrumental: um estudo sobre as crenças de auto-eficácia de músicos e instrumentistas. Dissertação (Mestrado em Música)-Departamento de Artes, Universidade Federal do Paraná, Curitiba, 2009.

GALVÃO. A. Cognição, emoção e expertise musical. Psicologia: Teoria e Pesquisa, Brasília, v. 22, n. 2, p. 169-174, ago. 2006

ZIMMERMAN, B. J. A social cognitive view of self-regulated academic learning. Journal of Educational Psychology, v. 81, n. 3, p.329-339, 1989. 